\title{
JOSEPHUS' RETELLING OF 1 KINGS 1 FOR A GRAECO-ROMAN AUDIENCE
}

\author{
Christopher Begg
}

\begin{abstract}
Summary
1 Kings 1 relates the tumultuous circumstances which eventuated in Solomon's being designated David's successor. This article offers a detailed comparison between the biblical account and its retelling by Josephus in his Antiquities 7:343-362. The study focuses on two overarching questions: (1) which text-form(s) of 1 Kings 1 did the historian utilize? and (2) what kinds of retelling techniques has he applied to the biblical data and with what purposes and effects did he employ those techniques?
\end{abstract}

\section{Introduction}

1 Kings 1 tells of the rather disreputable circumstances surrounding David's designation of Solomon as his successor: the aged king's decrepitude, Adonijah's grasp for power, the machinations of Nathan and Bathsheba, and the ignominious flight of Adonijah and his partisans. ${ }^{1}$ In this essay I wish to examine the retelling of the biblical chapter by Josephus in his Jewish Antiquities (hereafter Antiquities) 7:343-362. ${ }^{2}$ My study will address two overarching questions in

1 All these events are omitted in the Chronicler's presentation of Solomon's succession in $1 \mathrm{Chr} .22-29$ as a process initiated by the aged, but mentally unimpaired, David which unfolds without any trace of conflict or opposition.

2 For the text and translation of Ant. 7.343-362 I use R. Marcus, Josephus V (LCL; Cambridge: Harvard University Press; London: Heinemann, 1934): 544-55. I have likewise consulted the text and translation as well as the notes on the passage in E. Nodet, Les Antiquités Juives Livres VI et VII (Paris: Cerf, 2001): 229-34*. See also the annotated translation of the segment in C. T. Begg, Flavius Josephus Judean Antiquities 5-7 (Flavius Josephus Translation and Commentary, 4; Leiden: Brill, 2005): 299-304. Josephus incorporates his version of $1 \mathrm{Kgs} 1$ (= Ant. 7.343-362)

https://tyndalebulletin.org/

https://doi.org/10.53751/001c.29206 
particular: (1) With which of the varying ancient textual witnesses for 1 Kings 1, that is Masoretic Text (hereafter MT), ${ }^{3}$ Codex Vaticanus (hereafter $\mathrm{B})^{4}$ and the Antiochene or Lucianic (hereafter L) manuscripts ${ }^{5}$ of the Septuagint (hereafter LXX), Vulgate, ${ }^{6}$ and Targum Jonathan of the Former Prophets ${ }^{7}$ do Josephus' affinities lie? and (2) What kinds of retelling techniques does the historian apply to the data of his Vorlage [n] and what is distinctive about his version as a result of their application?

To facilitate my comparison between them, I divide up the material of 1 Kings 1:1-53 and Antiquities 7:343-362 into six parallel segments as follows: David \& Abishag (1:1-4//7:343-344); Adonijah's move (1:5-10//7:345-347); Nathan and Bathsheba's initiative (1:11-31// 7:348-352); David's directives realised (1:32-40//7:353-358); Jonathan's report (1:41-48//7:359-360); and Solomon spares Adonijah (1:49-53//7:361-362).

\section{David and Abishag}

1 Kings 1:1 presents David at the end of his reign: old and unable to get warm even when covered with clothes. Josephus' expanded version

within his rendering of the alternative presentation of Solomon's designation found in 1 Chr. 22-29 (= Ant. 7.335-342, 363-382) mentioned in n.1.

3 The text of $5 \mathrm{QKgs}$, preserving $1 \mathrm{Kgs} 1: 16-17,27-37$, is identical with that of MT. See the translation of the segment in M. Abegg, Jr et al., The Dead Sea Scrolls Bible (San Francisco: Harper, 1999): 261.

4 For the B text of 1 Kgs (3 Rgns) 1, see A. E. Brooke, N. Maclean, and H. StJ. Thackeray, ed., The Old Testament in Greek according to the Text of Codex Vaticanus, II:I I and II Samuel (Cambridge: University Press, 1927): 201-06. B 3 Rgns 1 is part of one of the manuscript's so-called kaige segments in 1-4 Rgns, i.e. 2 Rgns 11:2-3 Rgns 2:11 (the other is 3 Rgns 22:1-4 Rgns 25:30). In contrast to B's non-kaige sections (i.e. 1 Rgns 1:1-2 Rgns 11:1; 3 Rgns 2:12-21:43) in 1-4 Rgns, these kaige segments have undergone noteworthy assimilation to the (proto-)MT and so are of less significance as a witness to the text of the Old Greek Rgns than are the former. See D. Barthlélemy, Les Devanciers d'Aquila (VTSup 10; Leiden: Brill, 1963): 34-41, 91-143.

5 For the L text of $1 \mathrm{Kgs} 1$, see N. Fernández Marcos and J. R. Busto Saiz, ed., El texto antioqueno de la Biblia Griega, I: 1-2 Samuel (TECC 50; Madrid: CSIC, 1989): 166-71 (in this edition $1 \mathrm{Kgs} 1$ [MT] appears at the end of 2 Sam. [2 Rgns] as its ch. 25).

6 For the Vulgate text of $1 \mathrm{Kgs} 1$, see R. Gryson, ed., Biblia sacra iuxta vulgatam versionem (Stuttgart: Deutsche Bibelgesellschaft, 1994): 455-58.

7 For the targumic text of $1 \mathrm{Kgs} 1$, see A. Sperber, ed., The Bible in Aramaic, II (Leiden: Brill, 1959): 212-15 and for the translation D. J. Harrington and A. J. Saldarini, Targum Jonathan of the Former Prophets (Aramaic Bible, 10; Wilmington, Delaware: Glazier, 1989): 211-14. 
(7:343a) spells out the connection between the king's age and his bodily condition: 'Now as David was already very old, and, because of his age, his body felt cold and numb, ${ }^{8}$ so that not even by the heaping on of many garments could he kept warm.'

In response to David's predicament, 'his servants' propose $(1 \mathrm{Kgs}$ $1: 2$ ) that a 'young maiden' be found for the king who would warm him by 'lying in his bosom' (MT LXX L; 'with you', LXX B). Josephus (7:343b) attributes the proposal to a more specialized group around the king: 'his physicians 9 came together and advised that a beautiful virgin be chosen out of the whole country ${ }^{10}$ to sleep with the king, as it would help him against the cold to have the maid warm him., ${ }^{11}$

1 Kings 1:3 reports a nation-wide search for a 'beautiful maiden' that results in 'Abishag the Shunammite' being brought to David. The extant text of Josephus (7:344a) lacks an indication concerning the woman's place of origin 'a woman was found in the city of $[\ldots],{ }^{12}$ a woman who surpassed all others in beauty, ${ }^{13}$ Abisakē ('A $\beta$ $\left.\sigma a ́ k \eta\right){ }^{14}$ by name'.

Once brought to the king, Abishag becomes his nurse and ministers to him $(1: 4 \mathrm{a} \beta \mathrm{b} \alpha)$, while David, for his part, 'knows her not' $(1: 4 \mathrm{~b} \beta)$.

\footnotetext{
8 Throughout this essay, I italicise elements of Josephus' presentation like the above which lack a direct parallel in $1 \mathrm{Kgs} 1$. Biblical quotations follow the RSV.

9 One finds an analogous case in Ant. 6.166 where Saul's 'physicians' - rather than the royal 'servants' of 1 Sam. 16:15 - urge that a musician be found to soothe the spirit-troubled king Cf. also Ant. 10.25 where, in an addition to the story of Hezekiah's sickness (2 Kgs 20:1-11//Isa. 38:1-22), Josephus states that 'all hope for him was given up by his physicians'. These references doubtless have in view the Greco-Roman courts of Josephus' time where a body of medical professionals were in attendance on the ruler.

10 Josephus anticipates the above italicised elements of the physicians' proposal from the notice on the execution of the servants' suggestion of 1:2 in 1:3: 'so they sought for a beautiful maiden throughout all the territory of Israel'.

11 Cf. the concluding words of the servants' proposal in 1:2: 'let her lie in your [David's] bosom, that my lord the king may be warm'. Josephus leaves aside their preceding suggestion regarding the woman: ('let her wait upon the king, and be his nurse') which appears irrelevant to the king's need for warmth.

12 Marcus's above rendering reflects his opinion that the name of the city ('Shunem',

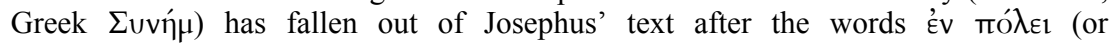
alternatively that the following word ruví 'woman' is a corruption of this, as suggested by C. Boysen). By contrast, Nodet translates 'dans une ville' and comments that the name of the town was unimportant to Josephus. Pirqe R. El. 33.3 makes 'Abishag the Shunammite' the sister of the Shunammite woman of Elisha's time (see 2 Kgs 4:8-37; 8:1-6).

13 Josephus embellishes $1 \mathrm{Kgs} 1: 4 \mathrm{a}$ which calls Abishag 'very beautiful'.

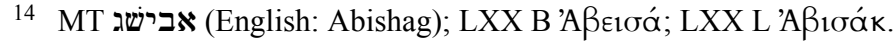


The historian's version (7:344b) clarifies the nature of Abishag's ministrations, spells out the reason for the royal abstinence, and elucidates the biblical 'know'-euphemism: 'but she merely slept in the same bed with him and kept him warm, for at his age he was too feeble to have sexual pleasure (tǻpoóíora) ${ }^{15}$ or intercourse with her., ${ }^{, 16}$ Concluding the story's first scene, Josephus appends (7:344c) a notice that looks ahead to the further course of the narrative in which Adonijah will request to marry Abishag (see Antiquities 8:5//1 Kgs 2:17): 'Of this virgin, however, we shall speak a little later., 17

\section{Adonijah's Move}

1 Kings 1:5 shifts attention from royal sickroom to the initiatives taken by the impatient crown prince, Adonijah, that is his declaration ('I will be king') and his preparing chariots, horsemen, and fifty men to run before him. ${ }^{18}$ Josephus (7:345) amplifies this presentation with items concerning Adonijah's person (his handsomeness and birth order relationship to Absalom) that he anticipates from 1:6b:

Now the fourth son of David ${ }^{19}$ a tall and handsome youth ${ }^{20}$ borne to him to him by his wife Agithē (AYînऽ) ${ }^{21}$ and named Adōnias, ${ }^{22}$ had

15 Josephus' one other use of the nominalised adjective áppodíoıs is in Ant. 8.191

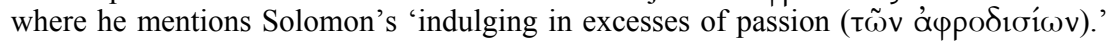
The use of the same term for both David and Solomon sets up a sharp contrast between the former who is 'too feeble for sexual pleasure' and his son who indulges in such pleasure to excess.

16 With the Josephan (and biblical) picture of the decrepit David and the passive, silent Abishag, cf. the account of them given in $b$. Sanh. 22a. Here, Abishag takes the initiative in proposing that she and David marry. When David responds that he already has the number of wives legally permissible for a king, she proceeds to taunt him with his impotence that he is attempting to cover up by his invocation of the Law. Thereupon, David summons Bathsheba and has multiple acts of intercourse with her.

17 Josephus often interjects such Vorverweise (as also Rückverweise) into his version of biblical history. The devise helps tie together the parts of his extended presentation.

18 B. Sanh. $21 \mathrm{~b}$ comments regarding Adonijah's declaration that when he attempted to put the crown upon his head, it did not fit him - a sure sign that he was not intended to be king. It further states that Adonijah's 'runners' heightened their speed by having their spleens and the flesh of the soles of their feet removed.

19 Josephus derives this indication from 2 Sam. 3:4 (//Ant. 7.21) where Adonijah appears fourth in the listing of David's older sons, following Amnon, Chileab (like 1 Chr. 3:3 Josephus calls this figure Daniel), and Absalom.

20 Cf. 1:6a: 'He [Adonijah] was also a very handsome man.'

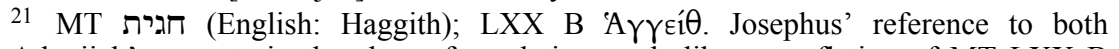
Adonijah's parents in the above formulation reads like a conflation of MT LXX B $1 \mathrm{Kgs}$ 1:5 (Adonijah the son of Haggith) and LXX L (Adonijah the son of David). His 
thoughts similar to those of Absalom and, aspiring to be king himself, ${ }^{23}$ told his friends that he ought to succeed to the royal power. ${ }^{24}$ So he provided himself with many chariots and horses (iтrmous) ${ }^{25}$ and fifty men to run before him.

1 Kings 1:6a notes parenthetically that David never displeased Adonijah by asking him 'why have you done thus and so?' Josephus (7:346a) both repositions and elaborates on this notice: 'When his father saw this, ${ }^{26}$ he did not rebuke him nor restrain him from his purpose, nor even go so far as to ask him why he did these things.'

The Bible's opening presentation of Adonijah continues in 1 Kings 1:7-8 with mention of those who did (Joab and Abiathar, v. 7) and did not (Zadok, Benaiah, Nathan, Shimei, Rei, and David's 'mighty men,' v. 8) support his claims. The historian reproduces this double listing with minor variations in 7:346b: 'And Adōnias had as accomplices the commander $\mathrm{Joab}^{27}$ and the high priest ${ }^{28}$ Abiathar $^{29}$; the only ones ${ }^{30}$ opposed to him were the high priest ${ }^{31}$ Sadok, the prophet Nathan, ${ }^{32}$

wording likewise avoids the ambiguity of 1:6b which translates literally as 'she [Haggith] bore him [Adonijah] after Absalom' and which could be understood as saying (erroneously) that Haggith was the mother also of Absalom. Cf. Vulgate's rendering 'secundus natu post Absalom.'

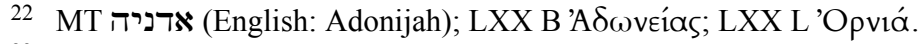

23 Josephus inserts this reference to the thinking behind Adonijah's initiatives as cited in 1:5. He likely found inspiration for his paralleling Adonijah's thoughts with those of Absalom in the mention of the former being born 'next after' the latter in 1:6b (as well in the obvious similarity between the actions of the two princes, both of whom attempted to seize royal power during David's lifetime and both of whom surrounded themselves with chariots, horses/horsemen and 'runners'; see 2 Sam. 15:1 [Absalom] and $1 \mathrm{Kgs}$ 1:5 [Adonijah]).

24 Josephus supplies an addressee for Adonijah's declaration ('I will be king') of 1:5a.

25 In MT and LXX BL 1:5b the reference is to 'horsemen'.

26 With his prefatory indication, Josephus makes clear that David's failure to confront Adonijah was not due to ignorance of his son's provocative behaviour; the 'this' which the king 'sees' is Adonijah's claiming the kingship for himself and his assembling of the armed force spoken of in 7.345.

27 In 1:7 Joab is identified rather as 'son of Zeruiah'. On Joab's status as David's 'commander,' see Ant. 7.110 (=2 Sam. 8:16; 20:23).

28 In 1:7 Abiathar is simply called 'the priest'.

29 According to 1:7 Adonijah 'conferred with' the pair of leaders, who themselves 'helped' him.

$30 \quad 1 \mathrm{Kgs}$ 1:8 does not thus limit Adonijah's non-supporters solely to those it lists.

31 Kgs 1:8 calls 'Zadok' simply 'the priest'; see n. 28.

32 In 1:8 Nathan appears in third place, after Benaiah. Josephus reverses the order of appearance of the two figures, conforming this to the sequence of 1:10 (//7.347). 
Banaias, the chief of the bodyguards, ${ }^{33}$ David's friend ( $\varphi$ í $\lambda \circ \varsigma$ ) Simūeis ${ }^{34}$ and all the foremost warriors.'

The account of Adonijah's initiatives in 1:5-10 culminates in 1:9-10 with mention of the prince's sacrifice at a site outside Jerusalem (v. 9a) and those whom he does (v. 9b) and does not (v. 10) invite to this. The Josephan rendition of this sequence (7:347) goes its own way in many particulars:

And Adōnias prepared a dinner ${ }^{35}$ outside the city beside the spring in the royal garden $(\pi \alpha \rho \alpha \delta \varepsilon i ́ \sigma \omega)$, ${ }^{36}$ and invited all ${ }^{37}$ his brothers except Solomon $^{38}$; he also brought with him the commander Joab and Abiathar ${ }^{39}$ and the chiefs of the tribe of Judah, ${ }^{40}$ but he did not invite to the feast either the high priest Sadok, ${ }^{41}$ or the prophet Nathan or Banaias, the chief of the bodyguard, ${ }^{42}$ or any of the opposing party. ${ }^{43}$

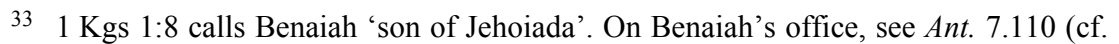
2 Sam. 8:18; 20:23 where he is designated as 'commander of the Cherethites and the Pelethites').

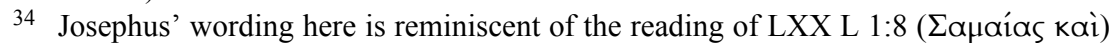
oi Ėtã̃por aưtoũ where the (second) proper name in the MT (and LXX B) sequence, i.e. '(Shimei and) Rei' is (mis-)construed as the common noun רע ('friend').

35 Cf. 1:9 (MT): 'Adonijah sacrificed sheep, oxen, and fatlings'. Josephus turns the occasion into a (secular) banquet.

36 Josephus' triple indication concerning the location of the affair takes the place of the two-part reference to this in 1:9, i.e. 'by the Serpent's Stone [MT אבן הזחלת] which is beside En-rogel.' In Josephus' rendering, mention of the 'stone' disappears and the 'spring' (Josephus uses the same translation for MT's עין i.e. זךץ' as does

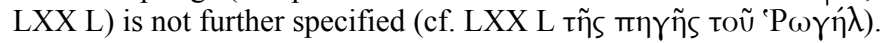

37 This term reflects the reading of MT LXX L 1:9; LXX B lacks an equivalent.

38 Josephus anticipates this qualification of the preceding reference to 'all his [Adonijah's] brothers' from 1:10 which lists Solomon among those not invited by Adonijah; it takes the place of the appositional phrase used in reference to Adonijah's brothers in 1:9 (MT LXX L, > LXX B) itself, i.e. 'the king's sons.'

39 With this phrase Josephus fills a surprising gap in the list of Adonijah's guests given in 1:9, i.e. the pair whom 1:7 identified as his chief supporters. He does so on the basis of 1:19 where Bathsheba reports Adonijah's inviting of the two men to David.

40 Cf. 1 Kgs 1:9 'all [> LXX B] the royal officials of Judah.'

41 Marcus's translation here follows the shorter reading of the codices RO and the Latin translation (Lat). Nodet adopts the more expansive reading of the codices SP

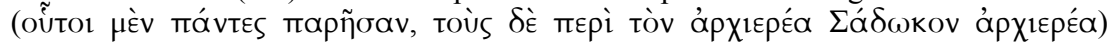
which he renders 'Tous-ceux-là étaient présents, mais l'entourage du grand prêtre Sadoq'. In any case, there is no mention of Zadok in the list of those not invited by Adonijah in 1:10 - suprisingly so since in 1:8 he is mentioned first among those who were 'not with' Adonijah. Here again (see n. 39), Josephus fills a gap left by the biblical account.

$421 \mathrm{Kgs}$ 1:10 simply mentions Benaiah by name. Josephus repeats the title he had used for him in 7.346.

43 This generalizing allusion to everyone else not invited by Adonijah takes the place of the two concluding items in the listing of 1:10, i.e. 'or the mighty men [see 1:8] or 


\section{Nathan and Bathsheba's Initiative}

The long middle segment of 1 Kings 1:11-31 (//Antiquities 7:348-352) features the countermove taken by Nathan and Bathsheba in response to Adonijah's threatening initiative. The unit begins in 1:11 with Nathan's direct address question to Bathsheba: 'Have you not heard that Adonijah ... has become king and David ... does not know it?' As he does frequently in his retelling of the Bible, Josephus (7:348a) turns Nathan's direct into indirect discourse, ${ }^{44}$ likewise rendering his question as a statement: 'These things the prophet ${ }^{45}$ Nathan reported to Solomon's mother Bersabē, ${ }^{46}$ saying that Adōnias was king and David did not know it. ${ }^{47}$

Having alerted Bathsheba to Adonijah's move in 1:11, Nathan proceeds to suggest a way of saving her and Solomon's life (v. 12), that is she is to approach David and remind him of his sworn promise that Solomon would succeed him (v. 13), whereupon Nathan will enter and second her words (v. 14). Josephus' version (7:348b-349a) of this sequence follows the Bible's presentation rather closely:

(7:348b) At the same time he advised her to save herself and her son Solomon, and to go alone $e^{48}$ to David and tell him that, although he has sworn that Solomon should be king after his death, ${ }^{49}$ Adōnias had

Solomon his brother'. Josephus anticipated the name 'Solomon' to an earlier point in 7.347; see n. 38 .

44 On this phenomenon, see C. T. Begg, Josephus' Account of the Early Divided Monarchy (AJ 8,212-420) (BETL 108; Leuven: Leuven University/Peeters, 1993): 1213, n. 38 .

$451 \mathrm{Kgs}$ 1:11 does not use this title for Nathan. Josephus supplies it on the basis of its occurrences in 1:8,10. On the historian's general tendency to introduce the title where the Bible lacks it, see L. H. Feldman, 'Prophets and Prophecy in Josephus', JTS 41 (1990): 386-420, esp. 389-91.

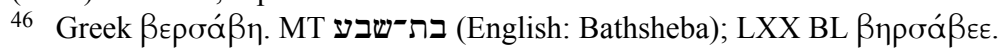

47 Marcus's above rendition of the conclusion of Nathan's opening announcement corresponds to the reading of MSPELat (which Nodet adopts as well). After 'Adōnias' the codices RO have simply the words $\beta \alpha_{\sigma 1} \lambda \varepsilon \tilde{u} \sigma_{\alpha} \alpha_{1} \beta o u ́ \lambda \varepsilon \alpha_{1}$ ('wishes to be king').

48 In $1 \mathrm{Kgs}$ 1:13 Nathan urges Bathsheba to go 'at once' to David. Josephus' formulation has in view the separate entrances of the pair that Nathan's scheme envisages.

49 Cf. the direct discourse question Nathan urges Bathsheba to ask David in 1:13a: 'Did you not ... swear ... saying "Solomon your son shall reign after me, and he shall sit upon my throne"?' The Bible contains no record of such a prior oath by David to Bathsheba. This raises the question of whether the purported oath is a fictitious one designed to induce the senile David to designate Solomon king; see the commentaries. Josephus, in any case, does not seem to have found any problem with reproducing the biblical mention of it (even though he too has not previously mentioned it). 
meanwhile taken over the royal power. ${ }^{50}$ (7:349a) And the prophet [see n. 45] said that while she was telling this to the king, he himself would enter and confirm her words.

1 Kings 1:15-16 relates the immediate sequels to Nathan's proposal: Bathsheba enters the king's chamber (v. 15a), ${ }^{51}$ pays him homage, and is asked what she wants by David (v. 16). Josephus replaces (7:349b) the king's question with Bathsheba's request that she be allowed to address him: 'So Bersabē took Nathan's advice and went to the king ${ }^{52}$; then, after doing obeisance and asking for permission to speak.'

Bathsheba now addresses David at length (see 1:17-22). She begins (vv. 17-18) by recapitulating elements of Nathan's discourse to her of 1:11-14. Avoiding the Bible's verbal repetition, Josephus (7:350a) reduces Bathsheba's opening word to a summary allusion to what Nathan had just said: 'she recounted to him all that the prophet [see note 45] had suggested.' In 1:19 Bathsheba begins expanding on the words given her by Nathan, telling David of Adonijah's 'sacrifice' and of those whom he did and did not invite to this. The Josephan rendering rearranges the order in which Bathsheba mentions Adonijah's guests and adds a reference to Solomon's 'friends' who were also not invited. It reads: 'telling him of Adōnias's dinner, ${ }^{53}$ and the guests who had been invited by him, and mentioning Abiathar, the high priest, and Joab the commander, and the king's sons, ${ }^{54}$ except Solomon and the latter's closest friends. ${ }^{55}$ Bathsheba concludes her address in 1:20-21 by reminding David that 'all Israel' awaits his designation of a successor (v. 20) and alluding to the threat hanging over both her and her son (v. 21). The Josephan rendition (7:350b),

50 Cf. the question Bathsheba is to ask David according to $1: 13 \mathrm{~b}$ : 'Why then is Adonijah king?' The codices RO read a different and more expansive version of the above words, this translating as 'if indeed Adōnias had already taken over the royal power, and to inquire of the king concerning this matter' (Marcus, Josephus V: 549, n. a).

51 In $1: 15 \mathrm{~b}$ there is a parenthetical reference to David's being 'very old' and Abishag 'ministering to him' to which Josephus has no equivalent.

$521 \mathrm{Kgs} \mathrm{1:15a}$ specifies that she went 'into his chamber.'

53 Just as he did in the case of 1:9 in 7.347, Josephus substitutes this occasion for the 'sacrifice' of Adonijah to which Bathsheba refers in 1:19.

54 In $1 \mathrm{Kgs}$ 1:19, Bathsheba mentions David's sons in first place, prior to Abiathar and Joab.

55 In $1 \mathrm{Kgs}$ 1:19 Bathsheba designates the non-invited Solomon as 'your [David's] servant'. Josephus' appended reference to the exclusion also of Solomon's 'closest friends' apparently refers to the persons listed in 7.346 as Adonijah's opponents whom (7.347) he did not invite to his banquet. 
inter alia, heightens the dramatic urgency of Bathsheba's invocation of what could happen to herself and Solomon: 'She added that all the people were waiting to see whom he would choose king, and urged him to bear in mind, that if after his death, ${ }^{56}$ Adonias became king, ${ }^{57}$ he would put her and her son Solomon to death. ${ }^{58}$

The scene in David's chamber takes a new turn in 1:22-27 as Nathan appears and addresses the king at length. In describing the prophet's entrance, Josephus (7:351a) renders the wording of 1:22-23 more specific in several respects: 'While his wife was still speaking, the keepers of the chamber announced that Nathan wished to see him, ${ }^{59}$ and, when the king bade them admit him, he entered. ${ }^{60}$

Nathan begins his words to David with a direct-address question (1:24) in which he asks whether the king has indeed proclaimed Adonijah his successor. Here too, Josephus (7:351b) has recourse to indirect address: 'and inquired whether David had that day declared Adōnias king and given over the royal power to him'.

Having posed his question, Nathan (1:25-26) proceeds to adduce the evidence prompting the question, i.e. the royal airs Adonijah has just now assumed. Thereafter, he rounds off his discourse with a further question (v. 27), now asking if David stands behind Adonijah's initiatives, even while neglecting to inform his servants about his choice of king. The historian's version (7:352) of this sequence, for example, turns its concluding question into a declaration by the prophet about what may legitimately be expected of the king:

56 Josephus replaces Bathsheba's euphemistic expression 'sleep with his [David's] fathers' of 1:21 with this clear-cut equivalent.

57 With this inserted phrase Josephus has Bathsheba spell out the situation that will give rise to danger for herself and Solomon (cf. her opening words of 1:21: 'otherwise [i.e. if David fails to designate his own successor, 1:20] it will come to pass [...]').

58 Cf. the less dramatic, passive formulation used by Bathsheba in 1:21: 'I and my son Solomon will be counted as offenders'. Josephus' Bathsheba makes explicit from whom (Adonijah) the threat will emanate and the seriousness of that threat (execution of herself and Solomon).

59 Cf. 1:22-23 where Nathan first 'comes in' (v. 22b), whereupon an unspecified 'they' inform David 'Here is Nathan the prophet' (v. 23a). Josephus clarifies both who tells David of Nathan's arrival and the purpose of his coming.

60 Josephus inserts this response by David to the retainers' announcement of Nathan's presence; the addition highlights the king's control of the proceedings - Nathan does not enter until he has been given explicit permission to do so. Conversely, Josephus leaves aside the reference to Nathan's prostration before David mentioned in 1:23b. Perhaps, Josephus found this gesture incompatible with Nathan's prophetic dignity (note that such an obeisance is not mentioned in connection with Nathan's interactions with David in 2 Sam. 7 and 12). 
for, he said, he [Adonijah] had prepared a splendid dinner, ${ }^{61}$ and had invited all the king's sons, except Solomon, ${ }^{62}$ and the commander Joab, ${ }^{63}$ and they were feasting to the accompaniment of clapping of hands and much jesting ${ }^{64}$ and were wishing Adōnias lasting sovereignty. ${ }^{65}$ 'But,' he added, 'he invited neither $\mathrm{me}^{66}$ nor the high priest Sadok, nor Banaias, the chief of the bodyguard, and it is right that all should know whether this was done with your approval. ${ }^{67}$

\section{David's Directives Realised}

David's initial response to Bathsheba and Nathan's overture comes in 1 Kings 1:28-30 where he summons the former (v. 28), and swears (v. 29) that he will now act on his earlier oath to her by appointing Solomon his successor (v. 30). Josephus (7:353) inserts a reference to Bathsheba's previous absence, and, in line with his regular practice, passes over the wording of the king's oath of verse $29^{68}$ :

When Nathan had spoken thus, the king ordered Bersabē to be summoned to him, - for she had hurried from the room when the prophet arrived ${ }^{69}$ - and when his wife came, ${ }^{70}$ he said, 'I swear to you

61 In 1:25 Nathan refers to Adonijah's 'sacrificing'. This is the third time that Josephus replaces mention of such sacrificing with a reference to a banquet put on by Adonijah (see 7.347//1:9; 7.350//1:19).

62 Josephus anticipates this qualification of the preceding reference, based on 1:25, to 'all David's sons' having been invited from 1:26 where Solomon is cited among those not invited by Adonijah. He proceeds similarly in 7.347; see n. 38 .

63 Josephus omits the name of Abiathar from Nathan's list of those invited in 1:25.

64 Josephus embellishes Nathan's statement of 1:25 ('they are eating and drinking before him [Adonijah]') with these further details that accentuate the group's complacency and frivolity - they are joking among themselves as David's life is ending.

65 Cf. 1:25: '(the guests are) saying "Long live King Adonijah".'

66 At this point, Josephus' version of Nathan's speech shifts to direct discourse. Such shifts within one and the same speech are not infrequent in the words Josephus attributes to his characters; see Begg, Josephus' Account: 123-24, n. 772. Josephus omits Nathan's self-qualification as 'your [David's] servant' of 1:26.

67 Cf. Nathan' closing question in 1:27: 'Has this thing been brought about by my lord the king and you have not told your servants who should sit on the throne of my lord the king after him?' Josephus' prophet is more direct in declaring that David's subjects have a right to hear about the matter from him.

68 David's oath in 1:29 runs: 'As the Lord lives, who has redeemed my soul out of every adversity'. Josephus' customary omission of the wording of such biblical oaths may be motivated by a concern to avoid any possible profanation of the divine name on the part of the speakers.

69 With this insertion, Josephus answers the question of why Bathsheba needs to be summoned at this point: she had not been present for Nathan's words to David. Such a clarification is called for, given that her exiting at the moment of Nathan's arrival was 
by Almighty God (tòv $\mu$ É $1 \sigma$ tov $\theta$ Éov) ${ }^{71}$ that your son Solomon shall assuredly be king, as I have sworn before, ${ }^{72}$ and he shall sit upon my throne $^{73}$; and it shall be this very day. ${ }^{, 74}$

Bathsheba responds (v. 31) to David's assurances with a prostration (cf. v. 16) and the wish that the king might 'live for ever'. Josephus' version (7:354a) attenuates the ironic hyperbole of Bathsheba's wish for the dying king: 'Thereupon she did obeisance to him and wished him long life.'

In 1:32 David proceeds to summon Zadok, Nathan, and Benaiah who appear before him. Supposing Nathan to be still in the king's presence, Josephus (7:354b) limits the royal summons to the other two figures: 'The king then sent for Sadok, the high priest, and Banaias, the chief of the bodyguard, and, when they came [...]'. The assembled officials are instructed by David in 1:33 to conduct Solomon, mounted on the royal mule, down to Gihon. The Josephan rendition $(7: 354 \mathrm{c}-$ 355a) amplifies this directive with several further details: 'he ordered them to take with them the prophet Nathan ${ }^{75}$ and the soldiers about the court, ${ }^{76}$ and, after mounting his son Solomon upon the royal mule, ${ }^{77}$ to

not mentioned previously by either the Bible or Josephus, this leaving readers wondering whether or not she was on hand for the prophet's intervention.

70 Josephus leaves aside the mention of Bathsheba's 'standing before the king' following her arrival in 1:28b.

71 In his oath of 1:29 (see n. 68), Josephus invokes 'the Lord' (Greek: Kúpios). Josephus virtually always avoids the Bible's use of 'the Lord' as a divine title, likely because such usage was not current in extra-biblical Greek; see Begg, Josephus' Account: 45, n. 218. Conversely, he uses the above designation 'Almighty God' with some frequency; on which, see A. Schlatter, Wie sprach Josephus von Gott? (BFCT, 14:1; Gütersloh: Bertelsmann, 1910): 18-19; Die Theologie des Judentums nach dem Bericht von Josephus (BFCT, 2.26; Gütersloh: Bertelsmann, 1932): 247 and n. 1.

72 Josephus substitutes this allusion to David's earlier oath for the king's citation of the words of that oath ('Solomon your son shall reign after me, and he shall sit upon my throne in my stead') of 1:30a.

73 In 1:30 this phrase is part of David's prior oath to Bathsheba which he now quotes to her; see previous note. Josephus turns it into an announcement concerning what is about to happen.

74 In reproducing Solomon's words of 1:29-30, Josephus, somewhat exceptionally, retains their direct address; see n. 44.

75 Here Josephus introduces a mention of Nathan, not as one of those to whom David addresses his orders (as in 1:32-33), but rather as a member of the group Zadok and Benaiah are to take with them.

76 Cf. 1:33 where those whom the three officials are to take along are designated more generally as 'the servants of your lord.'

77 Jewish tradition found difficulty with the idea of Solomon's riding on a mule, given that animal's hybrid nature, in view of the prohibition of 'mixtures' in Deut. 22:9. In response to the difficulty, $y$. Kil. 8.1 cites the opinion that the mule in question had 
lead him outside the city to the spring called ${ }^{78}$ Geiōn $\left(\Gamma \varepsilon 1 \omega v^{79}\right)$ '. David's instructions continue in 1:34a, where he directs Zadok and Nathan to anoint Solomon at the Gihon site. The historian $(7: 355 \mathrm{~b})$ inserts mention of the 'matter' to be used for the anointing: 'anoint

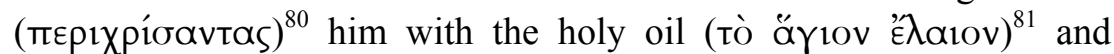
proclaim him king. This he commanded the high priest Sadok and the prophet Nathan to do. ${ }^{, 82}$ Once anointed, Solomon, David further enjoins, is to be acclaimed as king to the accompaniment of a trumpet blast (v. 34b) and then take his seat on David's throne as Israel's new king (v. 35a). In reproducing (7:356a) these concluding directives, Josephus rearranges and conflates: 'And he ordered them to accompany him through the midst of the city, ${ }^{83}$ blowing horns ${ }^{84}$ and shouting "May King Solomon sit upon the royal throne for ever!" ${ }^{\prime 5}$ in order that all the people might know $^{86}$ that he had been declared king by his father. ${ }^{87}$

been made during the six days of creation and so did not qualify as an forbidden hybrid.

78 Josephus supplies these details concerning the site ('Gihon') where Solomon is to be brought.

79 Cf. MT גחוך (English: Gihon); Josephus' form is the same as that found in LXX BL 1:33.

80 Josephus uses a compound of the verb employed by David in LXX 1:34,

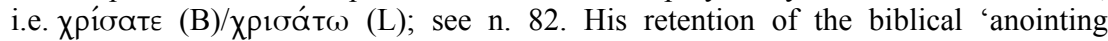
language' in this instance is noteworthy in that generally he tends to avoid such language, out of a concern, it would seem, not to provoke Roman sensibilities regarding Jewish 'Messianism.' (Note that Josephus' only uses of the form xpiotós 'anointed' are in his [disputed] references to Jesus in Ant. 18.63 [bis]; 20.200.) On the topic, see L. H. Feldman, Studies in Josephus's Rewritten Bible (JSJSup, 58; Leiden: Brill, 1998): 382-89.

81 This phrase establishes a terminological link between Solomon and Israel's two earlier kings, both of whom are anointed with 'holy oil' in Josephus' presentation; see Ant. 6.83 (Saul), 157 (David). Josephus likely found inspiration for his mention of 'oil' in David's anointing directive in the reference to Zadok 'taking the horn of oil from the tent' just prior to Solomon's anointing in 1:39.

82 In thus having David direct both Zadok and Nathan to anoint Solomon, Josephus aligns himself with the plural form xpíoate used by LXX B in 1:34, whereas both MT (משח) and LXX L (Xpıбó $\tau \omega)$ make Zadok (alone) the subject.

83 Cf. 1:35aa: 'you shall come up after him.' Josephus specifies the route of the postanointing procession.

84 In 1:34 the instrument to be sounded is a 'trumpet.'

85 Josephus here conflates the prescribed acclamation of $1: 34 \mathrm{~b} \beta$ ('Long live King Solomon') with David's directive of $1: 35 \mathrm{a} \beta$ ('he [Solomon] shall come and sit upon my throne'). Whereas in the sequence of 1:34b-35a the trumpet-blowing and acclamation of Solomon (v. 34b) seem to take place at Gihon prior to the procession back to Jerusalem alluded to in v. 35aa, Josephus makes these measures an accompaniment of the procession.

86 Josephus inserts this phrase spelling out the purpose behind the horn-blowing and acclamation previously enjoined by David. The insertion picks up on Nathan's 
Finally, Josephus rounds off David's words to his officials with an allusion (7:356c) to the admonitions he gave Solomon himself on this same occasion. This element of the Josephan king's discourse appears to be inspired by David's statement in $1: 35 b \beta$ 'and I have commanded

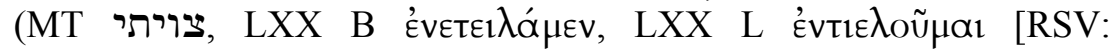
appointed]) him [Solomon] to be ruler over Israel and Judah.' In Josephus' rendition what David 'commands' Solomon concerns the

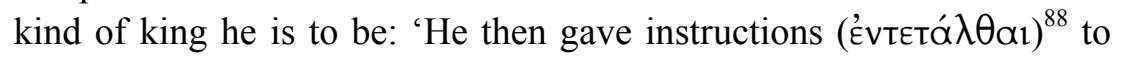
Solomon, concerning the kingdom in order that he might rule with piety


the tribe of Judah. ${ }^{90}$

Benaiah responds expansively to David's words of 1:33-35 in verses 36-37, expressing the wish that these might find fulfilment. Josephus (7:357a) reduces this sequence to a transitional phrase: 'Then after Banaias prayed that God might be gracious (Eن่ $\mu \varepsilon v \tilde{\eta})$ to Solomon. ${ }^{91}$

1 Kings 1:38 begins the account of the realization of David's directives to his three officials (1:33-35): they conduct Solomon, mounted on David's mule, to Gihon. Josephus' version highlights the alacrity with which David's order is carried out: 'without delaying a moment, they ${ }^{92}$ mounted Solomon upon the mule, escorted him to the spring outside the city. ${ }^{, 93}$

declaration to David in 7.352: 'it is right that all should know whether this was done with your approval.'

87 Cf. 1:35ba: 'for he [Solomon] shall be king in my stead.'

88 On the syntactical problems of this form in the context of 7.356, see Marcus, Josephus V: 553, n. a and Nodet, Antiquités VI-VII: 233, n. 2.

89 On these two qualities as key traits of Solomon in Josephus' presentation of him, see L. H. Feldman, Josephus' Interpretation of the Bible (Berkeley: University of California Press, 1998): 590-602.

90 In 1:35b $\beta$ David speaks of Solomon's kingship over 'Israel and Judah.' On Josephus' use of the term 'Hebrew[s]', often as a synonym for 'Israelite[s]', over the course of his history, see G. Harvey, The True Israel: Uses of the Names Jew, Hebrew and Israel in Ancient Jewish and Early Christian Literature (AGJU, 35; Leiden: Brill, 1996): 124-29.

91 In 1:37 Benaiah first expresses the hope that the Lord might 'be with' (thus the ketiv; the qere and LXX read a future form '[the Lord] will be with') Solomon as he had been with David. Josephus leaves aside Benaiah's further, 'undiplomatic' wish made in David's own presence - that the Lord will make Solomon's throne 'greater' than that of David himself.

92 1:38 spells out the identity of Solomon's attendants who set him upon the mule, i.e. Zadok, Nathan, and Benaiah, plus 'the Cherethites and the Pelethites' (cf. 1:32 where David instructs the three officials to take with them 'the servants of your lord').

93 In 1:38 Solomon is led to 'Gihon'. Josephus' wording regarding the site here echoes that used by him in 7.355 . 
Thereupon (1:39a) Zadok, having taken 'the horn of oil from the tent, ${ }^{, 94}$ anoints Solomon. ${ }^{95}$ Omitting the biblical details concerning the oil used, Josephus (7.357b) likewise makes the anointing the action of

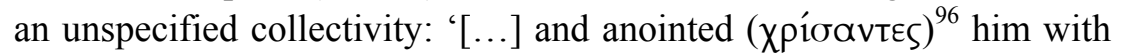
the oil.' 1 Kings 1:39b-40 then tells of the sequels to Solomon's anointing: the trumpet is blown, Solomon is acclaimed (v. 39b); the people follow after him, playing on pipes and rejoicing so loudly 'that the earth was split by [so MT LXX B; LXX L 'resounded with'] their noise.' The historian's account of these happenings (7:357c-358) evidences several adaptations, intended (in part) to align them with the orders previously given by David in 7:355:

(7:357c) then they brought him into the city ${ }^{97}$ with acclamations, praying that his reign would be a long one ${ }^{98}$ (7:358) and, having conducted him to the royal dwelling, they seated him upon the throne. ${ }^{99}$ And all the

94 The 'tent' in question is that which David pitched for the ark in Jerusalem; see 2 Sam. 6:17//1 Chr. 15:1//Ant. 7.86.

95 Jewish tradition asks why Solomon was anointed when this is not mentioned for most of Israel's kings. Tosefta Sanh. 4.11 and $b$. Hor. 11b suggest that royal anointing was performed only in cases of a contested royal succession (as happened with Solomon, given the prior claim of Adonijah).

96 With his use of this plural form (in contrast to the singular 'he [Zadok] anointed' of both MT and LXX BL 1:39), Josephus aligns David's order of 7.355 with its plural participle $\pi \varepsilon \rho 1 \chi \rho i ́ \sigma \alpha v t \varepsilon \varsigma$ having Zadok and Nathan as subjects and its execution here in 7.357; see n. 82. (LXX L 'harmonises' order and execution in the opposite direction: David uses a singular imperative with Zadok as subject in his anointing order [1:34] while Zadok [alone] performs the anointing according to 1:39.) See also 1:45, where in his report to Adonijah (that Josephus reduces to a phrase in 7.360), Jonathan makes Zadok and Nathan joint anointers of Solomon (thus MT and LXX B; here too LXX L uses a singular verb with Zadok as subject).

97 This interjected mention of the 'city' echoes David's directive in 7.355 that the newly-anointed Solomon be accompanied 'through the midst of the city.'

98 The above sequence conflates the two sequential actions spoken of at the end of 1:39 (the people say 'Long live King Solomon') and the beginning of 1:40 (they 'go up after' Solomon), of which the former appears to take place at Gihon. Josephus, by contrast, in line with the directive he ascribes to David 7.355 (see n. 85), has them both occur during the post-anointing procession through the city. In addition, Josephus leaves aside - for the moment, but see 7.359 - the mention of the trumpet-blowing of 1:39ba (cf. 7.355 where David prescribes the 'blowing of horns' as Solomon is being conducted through the city).

99 This notice lacks an equivalent in the account of the post-anointing events in 1:39b40. It does, however, have a basis elsewhere in $1 \mathrm{Kgs} \mathrm{1}$; see v. 35 (David directs that, following his anointing, Solomon is to 'come and sit upon my throne') and v. 46 (Jonathan reports to Adonijah's party that 'Solomon sits upon the royal throne'). Here, as often in 7.343-362, Josephus repositions elements that appear in a given context of the biblical account at a different point in his own presentation. 




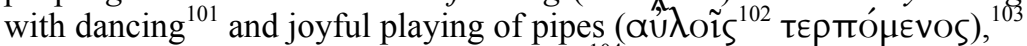
so that the multitude of their instruments ${ }^{104}$ caused the whole earth and the air $^{105}$ to resound $(\pi \varepsilon \rho 1 \eta \chi \in \tilde{i} \sigma \theta \propto 1) .{ }^{106}$

\section{Jonathan's Report}

With 1 Kings 1:41 attention shifts back to Adonijah's gathering, last mentioned in 1:10. At the same time, this new episode is closely linked with the preceding account of Solomon's anointing via the notice (v. 41a) that the whole party heard the 'noise' spoken of in 1:40 as they finished their feasting. Josephus' parallel (7:359a) adds mention of the effect of what they hear upon the company: 'When Adonias and those present at the dinner heard this noise, they were thrown into confusion.' In $1: 41 \mathrm{~b}$, Joab, the military man among the guests, raises the question: 'what does this uproar in the city mean?' Josephus' rendering turns the general's question into an ominous statement by him and appends a further reference to the agitated state of mind of the entire group 'and the commander Joab said that he was uneasy about the shouting and the

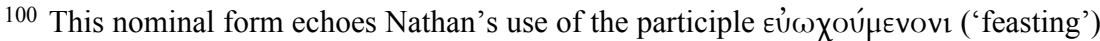
in his report to David about Adonijah's affair in 7.352. The wordplay reminds readers of that other, rival, 'feast' to which Josephus is about to return; see 7.359.

101 This item lacks a parallel in MT 1:40. It does, however, have an equivalent in the words kai éxópevov Év xopoĩs ("they whirled in dances') of LXX BL; see also the Targumic phrase משבהין בחנגיא '[the people] were praising him [Solomon] in dances'). In LXX B and the Targum the reference to 'dancing' takes the place of MT's mention of 'pipe playing,' whereas LXX L conflates the two readings - as does Josephus; see above.

102 This is the same word for 'pipes' used in LXX L 1:40.

103 Cf. 1:40a (MT and LXX L): 'playing on pipes, and rejoicing with great joy'. Josephus' formulation conflates these two elements.

104 This phrase lacks an equivalent in 1:40 (MT LXX L) where the earth is affected rather by the 'noise' of the pipes.

1051 :40b simply speaks of the effect of the noise on 'the earth'. Josephus' addition highlight the all-encompassing impact of the many instruments.

106 Josephus' term for the effect of the instruments corresponds to the readings of LXX


'resounded.' MT and LXX B speak rather of the noise 'splitting' the earth.
} 
trumpet blast ${ }^{107}$; and with the dinner before them, which no one tasted, ${ }^{108}$ all being occupied with their thoughts.'

An informant arrives in 1:42, namely Jonathan, ${ }^{109}$ the son of Abiathar the priest, whom Adonijah invites to enter, calling him a 'worthy man' and a bringer of 'good news'. Josephus (7:360a) interjects a reference to Adonijah's feelings on seeing the visitor: 'Adōnias was very glad to see the youth ${ }^{110}$ and called him a messenger

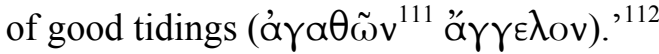

Jonathan responds to Adonijah's pleasantries with a lengthy report (1:43-48) about Solomon's designation by David which utilizes much of the same language employed by the narrator in what precedes. In view of the large-scale repetition involved, Josephus reduces $(7: 360 \mathrm{~b})$ Jonathan's whole report to its core content, ${ }^{113}$ formulating this as a transitional phrase: 'but, when he told them all about Solomon and the decision of King David'. ${ }^{114}$ Jonathan's report prompts (1:49) the immediate break-up of Adonijah's gathering; Josephus relates this outcome as follows: 'Adōnias and all the guests sprang up

107 Josephus here makes delayed use of the biblical mention of the blowing of a 'trumpet' following Solomon's anointing (see 1:39b; cf. David's directive about this in $1: 34)$ that he earlier passed over.

108 Cf. 1:41a where the reference is to the party's having 'finished eating' when they hear the noise from the city. In Josephus they 'refrain from eating,' once the disruption occurs. See Nodet, Antiquités VI-VII: 233*, n. 7.

109 This figure has appeared earlier in the Bible as one of the two messengers who brings the fugitive David news about rebel Jerusalem; see 2 Sam. 15:27; 17:17-21. He now reappears in the role of a bringer of fresh news from Jerusalem; his being the one to do this makes sense in that his father Abiathar is one of the key supporters of Adonijah at whose sacrifice he is a guest.

110 With this insertion on Adonijah's feelings, Josephus accentuates the irony of the contrast between the prince's expectations regarding Jonathan's message and what the latter is actually about to tell him.

111 This plural form is read by Marcus on the basis of Lat's boni. Nodet follows the singular reading of the Greek codices, i.e. '́räóv, this yielding a qualification of Jonathan himself as 'a good messenger.'

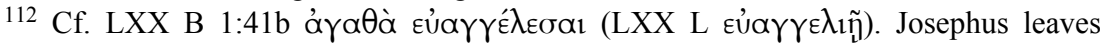
aside Adonijah's preceding designation of Jonathan as 'a worthy man' (cf. the Targumic 'fearing sinners,' דחיל חטאין).

113 Cf. his earlier abbreviation of Bathsheba's word to David of 1:17-18 (with its repetition of Nathan's previous word to her of 1:13) in 7.350a.

$114 \mathrm{Cf}$. Jonathan's opening summation of his entire report in 1:43: 'King David has made Solomon king.' 
('̊) each to his own home.'

\section{Solomon Spares Adonijah}

The story told in 1 Kings 1 terminates with the episode of King Solomon's (provisional) sparing of the suppliant Adonijah (1:50-53// 7:361-362). This happening is set in motion when the fearful Adonijah takes hold of the horns of the altar (1:50). Josephus (7:361a) interjects explanatory comments concerning both the import of this action and the nature of the altar 'horns': 'And Adōnias, being afraid of the king because of what he had done, ${ }^{117}$ became a suppliant to God (ikétns

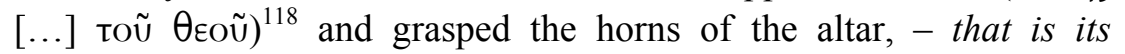
projections. ${ }^{119}$

Adonijah's initiative is reported to Solomon in 1:51, as is his appeal that the king swear not to execute him with the sword. The historian's rendition (7:361b) eliminates the extended repetition of wording used for Adonijah's deed in 1:50 in the report of this in 1:51, while also modifying the content of the suppliant's appeal: 'and this act of his was reported to Solomon, and also that he had asked to have a pledge from him that he would bear him no malice ${ }^{120}$ and do him no harm.'

Solomon responds (1:52) to the report of Adonijah's appeal with a double conditional statement that makes his fate (immunity versus death) dependent on his own behaviour (proving himself 'worthy' versus manifesting 'wickedness'). Josephus' formulation (7:362a) of Solomon's reply prefaces this with a positive characterisation of the


speaks more blandly of the guests 'rising,' while LXX B lacks an equivalent. Josephus omits the preceding reference to the company's 'trembling.'

116 Josephus' use of this term introduces a familiar element of the culture of his Graeco-Roman readers into the story.

117 Josephus inserts this motivation for Adonijah's 'fear' of Solomon as found in 1:50.

118 This phrase takes the place of the preceding verbal sequence of 1:50 '(Adonijah) arose and went' (LXX L adds, on the basis of $1 \mathrm{Kgs} 2: 29$, 'to the tent of the Lord').

${ }^{119}$ Like MT and LXX B 1:50, Josephus has no equivalent to the words, anticipated from 1:51, which Adonijah pronounces when grasping the altar horns according to LXX L 1:50, i.e. 'Let King Solomon swear to me today that he will not put his servant to death with the sword.'

120 With his phrase Josephus has Adonijah ask for assurances from Solomon, not only that he will not harm him (as in 1:51b), but also that he will not even harbour negative feelings towards him. 
king's reaction and then has him grant Adonijah an unconditional pardon for his recent offence, likewise recasting the figurative language of Solomon's assurance in 1:52. His version thus reads: 'Solomon with


this time without punishment for his offence, ${ }^{122}$ but said that if he were

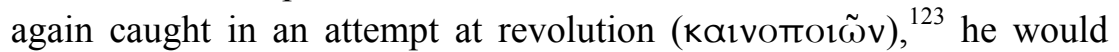
have himself to blame for his punishment., ${ }^{124}$

After admonishing Adonijah in 1:52, Solomon next has him brought before himself in 1:53a; once this is done, Adonijah pays homage to the king and is, rather curtly, dismissed by him (1:53b). Josephus (7:362b) depicts a more benign king, who has words also of assurance and good advice for the suppliant:

Then he sent men to remove him from his place of sanctuary (ikesías), ${ }^{125}$ and, when he came before him and did obeisance, Solomon ordered him to go back to his own house, without any fear ( $\mu \eta \delta \dot{v} v$ ú this would be to his own advantage. ${ }^{127}$

\section{Conclusion}

At the conclusion of this essay, I return to the overarching questions with which I began. The first of those questions concerned the textcritical affinities of Josephus' version of 1 Kings 1 . In fact, the relevant

121 This collocation occurs only here in Josephus.

122 Cf. Solomon's initial declaration concerning Adonijah in 1:52a: 'If he prove to be a worthy man [Targum: a man fearing sinners], not one of his hairs shall fall to the earth.' Josephus regularly eliminates or reformulates such figurative biblical language.

${ }^{123}$ With this term Josephus spells out the (political) nature of the 'wickedness' that will entail death for Adonijah to which Solomon alludes in 1:52b. The term further serves to associate Adonijah with the reprobate Zealot 'innovators, revolutionaries' (oi



124 Josephus' elaboration of Solomon's closing word of 1:52b ('he [Adonijah] shall die') highlights the suppliant's own responsibility for what will happen to him in the future.

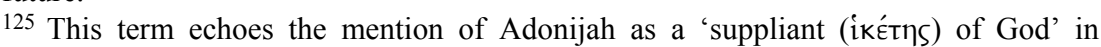
7.361. In 1:53a Solomon's retainers bring Adonijah down 'from the altar.'

126 With this appended word of assurance, Solomon assuages Adonijah's 'fearing' ( $\varphi \circ \beta \eta \theta$ eís) that earlier prompted him to take refuge at the altar; see 7.361.

127 Josephus continues his amplification of Solomon's curt order of 1:53b ('go to your house'). Having assured Adonijah that he has nothing to fear, the king now offers him useful and friendly advice about what would ensure his welfare in the future. In its expansiveness Solomon's word to Adonijah does indeed evidence the 'great mildness and moderation' Josephus attributes to the king at the start of 7.362. 
data turned out to be rather limited, especially given the historian's consistent tendency to paraphrase the Bible's presentation rather than to reproduce this verbally. At the same time, we did note several items of interest in this connection. Thus, for example, Josephus (7:358) agrees with LXX L against MT and LXX B 1:40 in mentioning both 'dancing' and the 'playing of pipes' following Solomon's anointing (see n. 101), just as he refers (7:358) to the earth's 'resounding' (so LXX L 1:40), rather than being 'split' (so MT LXX B) by the noise (see n. 106). In addition, he uses (7:360) the same verb ('spring up') for the action of Adonijah's party in reaction to Jonathan's report as does LXX L 1:49, whereas MT has them 'arise' and LXX B lacks an equivalent (see n. 115), while his reference to David's 'friend Simūeis' (7:346) might reflect the peculiar LXX L reading ('Samaias and his friends') in 1:8 (see n. 34). On the other hand, there are also indications of Josephus' use of a text of 1 Kings 1 having affinities with that of MT and/or LXX B. Thus, he employs, for example, a form of the name of the crown prince ('Adōnias') which is clearly closer to his MT and LXX B name ('Adonijah'/'Adōneias') than to LXX L's 'Ornia'. Like MT and LXX B 1:50 too he has no equivalent to the LXX L plus at the end of the verse anticipating the words of the suppliant Adonijah as reported to Solomon in 1:51b (see 7:361a; compare n. 119). In having David commission both Zadok and Nathan to anoint Solomon (7:355), he goes together with LXX B 1:34's plural imperative contra the singular of MT and LXX L (see n. 82). And finally, as pointed out in note 21, the historian's mention of the names of both parents of Adonijah in 7:345 reads like a conflation of MT and LXX B 1:5 (which call him Haggith's son) and LXX L (where he is referred to as David's son). These findings suggest that, whereas Josephus' primary text for 1 Kings 1 was a 'proto-Lucianic' one, he drew on other text-forms of the chapter as well. ${ }^{128}$

My second opening question related to Josephus' retelling techniques in Antiquities 7:343-362 and the distinctiveness of his version of Solomon's designation that results from their application.

128 On the question of Josephus' text for the Books of Kings overall, see M. V. Spottorno, 'Josephus' Text for 1-2 Kings (3-4 Kingdoms)' in VII Congress of the International Organization for Septuagint and Cognate Studies Paris 1992, ed. L. Greenspoon and O. Munnich (SBLSCSS, 41; Atlanta: Scholars Press, 1995): 14552. Spottorno concludes (p. 152) that for his version of Kings Josephus drew primarily on a Greek text that represented a first step in the development of the Antiochene/Lucianic text found in our (much later) L manuscripts. 
A first such technique is represented by the historian's many additions to/supplementations of the biblical account. Elements of the source presentation thus amplified by Josephus include: David's 'not knowing' Abishag (cf. 1:4b and 7:344b), Adonijah's initiatives (cf. 1:5 and 7:345a), the prince's guest list (cf. 1:9 and 7:347a, where Josephus adds the names of Joab and Abiathar), the enumeration of those not invited by him (cf. 1:10 and 7:347b, where Josephus introduces mention of Zadok), the entrances of Bathsheba (cf. 1:15-16 and 7:349b) and Nathan (cf. 1:22 and 7:351), the latter's report about Adonijah's celebration (cf. 1:25 and 7:352), David's response to Bathsheba (cf. 1:32 and 7:353a, where Josephus inserts mention of her previous exit and present recall), the happenings that follow Solomon's anointing (cf. 1:39b-40a and 7:357c-358a, where Josephus interjects reference to the enthronement of Solomon and to the people's 'feasting and merrymaking'), the extent of the area affected by the people's noise-making (cf. 1:40b and 7:358b, where Josephus has also 'the air' resounding), the state of mind of Adonijah's guests upon hearing the uproar (cf. 1:41 and 7:359), Adonijah's taking refuge at the altar (cf. 1:50 and 7:361), and Solomon's stance towards the fugitive (cf. 1:5253 and $7: 362)$.

Antiquities 7:343-362 also, however, offers many examples of the converse technique, that is elimination or abbreviation of source items, both on a smaller and a larger scale. Josephus' small-scale reductions of the biblical presentation are exemplified by his non-utilization of the parenthetical notice of 1:15b (David's age and Abishag's ministering to him), the reference to Nathan's prostration (1:22), the prophet's mention of Abiathar as one of Adonijah's guests (1:25) and of Zadok as among the non-invited (1:26), the wording of David's oath (1:29), Benaiah's wish that Solomon's throne be made greater than that of David (1:37b), and Zadok taking the horn of oil from the tent (1:39a). More conspicuous, however, is his drastic shortening of characters' speeches, especially where these involve verbal repetitions of what has already been said previously: compare 7:350a and 1:17-18 (Bathsheba's opening word to David); 7:360a and 1:43-48 (Jonathan's report); and 7:361b and 1:51 (the account of Adonijah's flight that is given to Solomon).

A third Josephan retelling technique that is much in evidence in our passage is the rearrangement of the biblical story's sequence. Instances of this phenomenon include the following: the incorporation of 
elements of 1:3 (the search for the maiden to keep David warm) into Josephus' version of 1:2 (the proposal concerning this) in 7:343b, the reversal of 1:6a (David's failure to discipline Adonijah) and 1:6b (additional personal details concerning Adonijah) in 7:345, the mention of Nathan prior to Benaiah (7:346; cf. 1:10), and of Abiathar before Joab (7:350; cf. 1:25), and the 'delayed' utilization of the notice on the trumpet-blowing of $1: 39 \mathrm{~b}$ in $7: 359$.

Finally, Josephus modifies and adapts the Bible's narrative in still other ways, terminologically, stylistically, and contentually. $\mathrm{He}$ substitutes the designation 'Almighty God' (7:353) for 'the Lord' of 1:30 (see n. 71). He regularly - though not invariably - recasts the source's direct address as indirect (see n. 44; cf. note 56), and turns speakers' questions into statements by them (e.g. 1:11 and 7:348a, Nathan; 1:27 and 7:356, Nathan; 1:41b and 7:359b, Joab). Biblical euphemisms and figurative language are replaced by unequivocal, prosaic renditions (cf. 1:4b and 7:344b, David's 'not knowing' Abishag; 1:21 and 7:350, David's 'sleeping with his fathers'; 1:52 and 7:362a, not a hair of Adonijah's falling to the ground). The proposal about keeping David warm is made by his 'physicians' (7:343), rather than his 'servants' (cf. 1:2). Abiathar and Zadok are called 'high priests' (7:346) rather than simply 'priests' (cf. 1:7-8), while Benaiah is identified by his title rather than by the name of his father (cf. 1:8 and 7:346). Adonijah's affair is a (secular) banquet, not a sacrifice (cf. 7:347 and 1:9 and passim). Bathsheba's request that she be allowed to speak (7:349b) takes the place of David's question about what she wants (1:16b). Her reference to herself and Solomon being 'counted as offenders' after David's death (1:21) is intensified in 7:350b where Bathsheba avers that the two of them will be 'put to death' by Adonijah. The indeterminate 'they' who tell David of Nathan's coming (1:23) are specified as 'the keepers of the chamber' (7:351a). Bathsheba's wish for the aged David is less hyperbolic than is the one ascribed to her biblical counterpart (cf. 1:31 and 7:353c). David 'commands' Solomon about how he is to rule the people as part of the initiatives he takes in response to Bathsheba and Nathan's intervention (7:356b) instead of referring to his previously 'commanding' Solomon to be the nation's king (cf. 1:35b). The horn-blowing and acclamation of Solomon enjoined by David (and subsequently performed by Solomon's entourage) are, it seems, to take place during the return procession to the city rather than at the anointing site itself (cf. 7:356a 
and $1: 34 b-35 a ; 7: 357 c-358 a$ and $1: 39 b-40 a)$. The actual anointing of Solomon is effected by an unspecified collectivity ('they', 7:357), not Zadok acting alone, as in 1:39a. And lastly, the pardon Solomon grants Adonijah is an unconditional one (see 7:362a) in contrast to the conditional exoneration given him in 1:52a, just as Adonijah's potential 'wickedness' to which Solomon alludes in 1:52b is elucidated in terms of the former 'attempting revolution' in the continuation of 7:362a. ${ }^{129}$

What now is distinctive about Josephus' presentation of Solomon's accession as a result of his applying the foregoing retelling techniques to the biblical account? Overall, the historian's version evidences a tendency to streamline his often repetitive Vorlage, the most obvious instance being the reduction of Jonathan's six-verse report (1:43-48) to a mere phrase in 7:360a. Conversely, however, the historian does sometimes fill source gaps and spells out matters the Bible leaves readers to ascertain for themselves: Why, for example, did David refrain from having relations with Abishag (cf. 1:4b and 7:344b)? Where is 'Abiathar' in the list of Adonijah's guests that Bathsheba reports to David (cf. 1:19 and 7:350)? Was Bathsheba present for the exchange between Nathan and David or not (see 7:353a)? What was the sense of Adonijah's action in grasping the 'horns' of the altar and what were those 'horns' (cf. 1:49 and 7:361a)? In the same line, Josephus endows his rendition with a greater clarity and credibility given his elimination/attenuation of the biblical story's euphemisms, figurative language, and hyperbole (see Bathsheba's wish the dying David might 'live for ever' in 1:31; cf. 7:353c). On the other hand, in certain cases Josephus employs more vivid and expansive language than does the Bible itself, for example, in his formulation of Bathsheba's claim about what will happen to her and Solomon after David's death (cf. 7:350b and 1:21) and Nathan's report about Adonijah's celebration (cf. 7:352 and 1:25). One likewise notes a concern for the observance of proper royal protocol in the historian's handling of the interactions between David and other personages:

129 The above techniques of addition/amplification, omission/abbreviation, rearrangement, and other modifications characterise, in ever-varying combinations, Josephus' entire rewriting of the biblical narrative in Ant. 1-11. One can find detailed treatments of the historian's handling of extended portions of the Bible's history in Begg, Josephus' Account, Josephus' Story of the Later Monarchy (AJ 9,1-10,185) (BETL 145; Leuven: University Press/Peeters, 2000). 
Bathsheba first asks the king for permission to speak (7:349c; cf. 1:16), Nathan does not enter until David has commanded his admittance (7:351; cf. 1:22-23), and Benaiah's undiplomatic wish that the throne of David's successor be greater than his own (1:37b) is passed over. Josephus also takes care to 'harmonize' David's directive about who is to anoint Solomon and its execution - in both cases a collectivity is involved (see 7:355b and 7:357b), whereas MT and LXX B 1:34 and 1:39a differ in this regard, and LXX L refers to Zadok as the sole anointer in both verses (see n. 96). He introduces as well allusions to both previous (Adonijah has thoughts like those of David's earlier rebel son, Absalom, 7:345) and later (he will return to the figure of Abishag subsequently, 7:344b; cf. 8:5) events of his history, thereby accentuating its interconnectedness. His reference to Adonijah's 'attempting revolution' (7:362) links that figure with the Zealot 'revolutionaries' of his own day (see n. 123), while the mention of Adonijah's symposium (7:361) associates the ancient biblical happening with an institution familiar to contemporary Graeco-Roman readers. Throughout, the feelings and psychology of the various characters receive more explicit attention via, for example, the historian's interjected notices on Adonijah's state of mind (7:345a; cf. 1:5), the agitation of Adonijah's guests upon hearing the noise from the city (7:359; cf. 1:41a), Joab's confession of his uneasiness (7:359; cf. 1:41b), Adonijah's being 'very glad' to see Jonathan (7:360a; cf. $1: 42 \mathrm{~b}$ ), his appeal that Solomon 'bear him no malice' (7:361b; cf. $1: 51 \mathrm{~b})$, and the 'mildness and moderation' of Solomon's response (7:362a; cf. 1:52). Lastly, our study has brought to light Josephus' retouchings of the Bible portraits of the story's characters. The age, decrepitude, and impotence of David is accentuated (cf. 7:343-44 and 1:1-4), as is his inertia vis-à-vis Adonijah's provocations (cf. 7:346 and 1:6a). Subsequently, however, Josephus portrays a newly reenergized David, who, among other things, instructs his son in 'ruling with piety and justice' (7:356b). ${ }^{130}$ As for the story's other, lesser characters, he highlights the incomparable beauty of Abishag (cf. 7:343b-344 and $1: 1-4)$. Nathan's stature is heightened by Josephus' recurrent application of the prophet title to him where the Bible lacks this (cf. e.g. $7: 348$ and $1: 11 ; 7: 349$ and $1: 14 ; 7: 350$ and $1: 17-18$ ), as well as by the omission of the mention $[1: 23 \mathrm{~b}]$ of his prostration before David

130 On Josephus' overall portrait of David, see Feldman, Interpretation: 537-69. 
(see n. 60). In Josephus' presentation of Adonijah, the latter's motivations are explicitly compared to those of the reprobate (and illfated) rebel Absalom (7:345); subsequently he is (misguidedly) 'very glad to see' Jonathan (7:360), becomes 'a suppliant of God' (7:361a), and seeks assurances that Solomon will 'bear him no malice' (7:361b). Of all the figures in the narrative, it is, however, Solomon whose portrayal is most markedly (and positively) retouched by Josephus. Prior to his anointing he is personally instructed by David about the kind of king he should be (that is 'pious and just', 7:356; cf. 1:35b). Solomon's response to Adonijah's appeal is characterised by Josephus as exhibiting 'great mildness and moderation'; he further grants Adonijah an unconditional rather than a conditional pardon, and shows himself far more sympathetic to the suppliant in their face-to-face exchange than does the biblical king (cf. 7:362 and 1:52-53). ${ }^{131}$

The story of 1 Kings 1 with its succession crisis, court intrigue, erotic element and minimally theological character was one which would naturally appeal to Josephus' primary audience in his Antiquities, that is cultivated, politically-minded Graeco-Roman readers. ${ }^{132}$ Accordingly, he reproduces the story in extenso and with considerable 'accuracy', each of the chapter's six component units as distinguished above having its counterpart in his own presentation. At the same time, Josephus, as we have seen, feels free to add to, leave aside, rearrange and otherwise modify numerous elements of the biblical narrative. Tracing (and attempting to make sense of) the interplay between the historian's essential fidelity to the Bible's account and the liberty with which he handles so many of its component details constitutes the particular interest of the kind of study attempted in this essay.

131 On Josephus' overall portrayal of Solomon, see Feldman, Interpretation: 570-628.

132 On this audience and what Josephus aimed to convey to it in the Ant., see Feldman, Interpretation: 46-49. 